\title{
Myofibroblasts in interstitial lung diseases show diverse electron microscopic and invasive features
}

\author{
Henna M Karvonen ${ }^{1,2}$, Siri T Lehtonen ${ }^{2,3}$, Raija T Sormunen ${ }^{4,5}$, Terttu H Harju ${ }^{1,2}$, Elisa Lappi-Blanco ${ }^{5,6}$, \\ Risto S Bloigu ${ }^{7}$ and Riitta L Kaarteenaho ${ }^{1,2}$
}

The characteristic features of myofibroblasts in various lung disorders are poorly understood. We have evaluated the ultrastructure and invasive capacities of myofibroblasts cultured from small volumes of diagnostic bronchoalveolar lavage (BAL) fluid samples from patients with different types of lung diseases. Cells were cultured from samples of BAL fluid collected from 51 patients that had undergone bronchoscopy and BAL for diagnostic purposes. The cells were visualized by transmission electron microscopy and immunoelectron microscopy to achieve ultrastructural localization of alphasmooth muscle actin ( $\alpha$-SMA) and fibronectin. The levels of $\alpha$-SMA protein and mRNA and fibronectin mRNA were measured by western blot and quantitative real-time reverse transcriptase polymerase chain reaction. The invasive capacities of the cells were evaluated. The cultured cells were either fibroblasts or myofibroblasts. The structure of the fibronexus, and the amounts of intracellular actin, extracellular fibronectin and cell junctions of myofibroblasts varied in different diseases. In electron and immunoelectron microscopy, cells cultured from interstitial lung diseases (ILDs) expressed more actin filaments and $\alpha$-SMA than normal lung. The invasive capacity of the cells obtained from patients with idiopathic pulmonary fibrosis was higher than that from patients with other type of ILDs. Cells expressing more actin filaments had a higher invasion capacity. It is concluded that electron and immunoelectron microscopic studies of myofibroblasts can reveal differential features in various diseases. An analysis of myofibroblasts cultured from diagnostic BAL fluid samples may represent a new kind of tool for diagnostics and research into lung diseases.

Laboratory Investigation (2012) 92, 1270-1284; doi:10.1038/labinvest.2012.95; published online 18 June 2012

KEYWORDS: alpha-smooth muscle actin; bronchoalveolar lavage; fibronectin; fibronexus; immunoelectron microscopy; pulmonary fibrosis

The myofibroblast was discovered four decades ago ${ }^{1-3}$ and it was initially defined in ultrastructural terms. ${ }^{4-6}$ The increased cytoplasmic contractility of myofibroblasts has been attributed to the presence of alpha-smooth muscle actin ( $\alpha$-SMA)-positive filaments. $^{7,8}$ The fibronexus (FNX) structure is a characteristic marker for the myofibroblast when the cells are examined in the transmission electron microscope (TEM), although its detailed molecular composition has not yet been fully characterized. The FNX is composed of intracellular $\alpha$-SMA-positive actin filaments, which are closely associated with longitudinally orientated extracellular fibronectin bundles. ${ }^{4,6,9-11}$

Three types of structures of FNXs have been described, namely track-, plaque- and tandem-like, of which the track- like is believed to be the most common. ${ }^{5}$ The numbers of myofibroblasts are increased in many kinds of interstitial lung diseases (ILDs), especially in idiopathic pulmonary fibrosis (IPF). Myofibroblasts are located in fibroblast foci, which are specific aggregates of fibroblasts and myofibroblasts. In tumors, stromal myofibroblasts are postulated to have a function in invasive cancer growth. ${ }^{12-14}$

We hypothesized that myofibroblasts may have diverse molecular compositions and distinct ultrastructural features in different types of lung disorders. Cells obtained from various lung disorders were cultured from small volumes of diagnostic bronchoalveolar lavage (BAL) fluid samples. The aim of our study was to analyze the myofibroblasts cultured

\footnotetext{
${ }^{1}$ Department of Internal Medicine, Respiratory Research Unit, Oulu University Hospital and Institute of Clinical Medicine, University of Oulu, Oulu, Finland; ${ }^{2}$ Clinical Research Center, Oulu University Hospital, Oulu, Finland; ${ }^{3}$ Department of Anatomy and Cell Biology, Institute of Biomedicine, University of Oulu, Oulu, Finland;

${ }^{4}$ Biocenter Oulu, University of Oulu, Oulu, Finland; ${ }^{5}$ Department of Pathology, Institute of Diagnostics, University of Oulu, Oulu, Finland; ${ }^{6}$ Department of Pathology, Oulu University Hospital, Oulu, Finland and ${ }^{7}$ Medical Informatics Group, University of Oulu, Oulu, Finland

Correspondence: Dr RL Kaarteenaho, MD, PhD, Department of Internal Medicine, Respiratory Research Unit, Oulu University Hospital and Institute of Clinical Medicine, University of Oulu, PO Box 20, Fi-90029, Oulu, Finland.

E-mail: Riitta.Kaarteenaho@oulu.fi

Received 21 September 2011; revised 7 May 2012; accepted 15 May 2012
} 
from BAL fluid samples by TEM, immunoelectron microscope (IEM), western blot and quantitative real-time reverse transcriptase polymerase chain reaction (qRT-PCR) with a special interest focusing on the ultrastructural expression of $\alpha$-SMA and fibronectin. The invasive capacity of BAL-derived cells was also tested. The study material included patients with different lung disorders such as IPF, nonspecific interstitial pneumonia (NSIP), connective tissue disease-associated ILDs (CVD-ILD), sarcoidosis, asbestosis, allergic alveolitis, lung carcinomas and pulmonary damage after drug reactions.

\section{MATERIALS AND METHODS Ethical Issues}

Each patient provided informed consent and the study had the approval from the ethical committee of the local hospital (64/2001, amendment 2005).

\section{Patients}

The study material was taken from diagnostic samples, a total of 98 patients were examined in the original study protocol (data not shown here). Those patients with lung infection or its suspicion were excluded. Colonies of proliferating fibroblastic cells could be seen in 61 samples (62\%). In 10 of the 61 cases, the cells reached senescence after the first passage. In 51 of the 61 cases, the cells proliferated for several passages and were used for the ultrastructural analyses described in this study. The study population was classified into 11 categories according to the diagnoses.

The BAL was obtained as recommended by the European Task Group on BAL. ${ }^{15}$ The lavage was carried out in the right middle or upper lobe or lingual. The aliquots of $20 \mathrm{ml}$ sterile saline at $37^{\circ} \mathrm{C}$ (for a total of $200 \mathrm{ml}$ ) were installed into the segment lavaged. The fluid recovered from the last aliquot was included into the study. The effluent was aspirated manually using a syringe. After the routine BAL, patients with BAL fluid recovery of $>100 \mathrm{ml}$ of the total amount of $200 \mathrm{ml}$ were included.

After the routine BAL fluid preparations, small volumes of BAL fluids (from 10 to $20 \mathrm{ml}$, average $15.4 \mathrm{ml}$, s.d. 2.4) were collected from 51 patients that had undergone bronchoscopy and BAL for diagnostic purposes in Oulu University Hospital during the years 2008-2010. Cultured BAL cells from every patient were examined in the electron microscope, and in selected cases with other methods (Table 1).

The clinical follow-up data and information of radiological and lung function findings were obtained from the patient records at the hospital, enabling the patients to be classified into eleven disease groups. Diagnostic BAL fluid samples were re-evaluated by a pulmonary pathologist. For a control of BAL fluid culture, peripheral lung tissue biopsy sample was obtained from one patient with IPF who had also undergone BAL. The cells cultured from the biopsy were used for comparison of BAL-cultured cells from that one particular IPF patient. A patient with allergic alveolitis was lavaged twice and cells from both BAL fluids were cultured. In addition, cells derived from normal peripheral lung tissues from four patients operated for lung cancer were cultured and analyzed by TEM and IEM. The cells cultured from lung tissue samples were used in the comparison of TEM and IEM findings from BAL-derived cells. Cells cultured from peripheral lung tissue of a non-smoking patient with normal lung were used as a control in western blot, qRT-PCR and IEM quantitation studies (see Supplemental material and Supplementary Table 1 in supplement for further information).

\section{Preparation of Lung Biopsy and Peripheral Lung Tissues} Cells cultured from lung resection samples from four patients with normal lung were used as controls for BAL-cultured cells. In addition, the cultured cells from both BAL and lung

Table 1 The study population and the methods used

\begin{tabular}{|c|c|c|c|c|c|c|c|c|c|c|c|}
\hline & \multicolumn{11}{|c|}{ Patients $(n)$} \\
\hline & $\begin{array}{l}\text { IPF } \\
\text { (11) }\end{array}$ & $\begin{array}{l}\text { NSIP } \\
(7)\end{array}$ & $\begin{array}{l}\text { CVD-ILD } \\
\text { (7) }\end{array}$ & $\begin{array}{l}\text { Asbestosis } \\
\text { (5) }\end{array}$ & $\begin{array}{l}\text { Sarcoidosis } \\
\text { (6) }\end{array}$ & $\begin{array}{c}\text { Allergic } \\
\text { alveolitis (3) }\end{array}$ & $\begin{array}{c}\text { Drug } \\
\text { reaction (4) }\end{array}$ & $\begin{array}{l}\text { Lung } \\
\text { cancer (2) }\end{array}$ & $\begin{array}{l}\text { Normal } \\
(1)\end{array}$ & $\begin{array}{l}\text { RB-ILD } \\
\text { (1) }\end{array}$ & Other (4) \\
\hline TEM & 11 & 7 & $7^{\mathrm{a}}$ & 5 & 6 & 3 & 4 & 2 & 1 & 1 & $4^{b}$ \\
\hline IEM & 11 & 7 & $7^{\mathrm{a}}$ & 5 & 6 & 3 & 4 & 2 & 1 & 1 & $4^{\mathrm{b}}$ \\
\hline Western blot & 7 & 7 & $7^{\mathrm{a}}$ & 5 & 6 & 3 & 4 & 2 & 1 & 1 & $3^{d}$ \\
\hline qRT-PCR & 7 & 7 & $7^{\mathrm{a}}$ & 5 & 6 & 3 & 4 & 2 & 1 & 1 & $3^{d}$ \\
\hline
\end{tabular}

Abbreviations: CVD-ILD, collagen-vascular disease associated with interstitial lung disease; RB-ILD, respiratory bronchiolitis associated interstitial lung disease.

${ }^{\mathrm{a}}$ Rheumatoid arthritis $(n=3)$, Sjögren syndrome $(n=2)$ and scleroderma $(n=2)$.

${ }^{\mathrm{b}}$ Asthma $(n=2)$, COPD + emphysema $(n=1)$ and vasculitis $(n=1)$.

${ }^{c}$ Rheumatoid arthritis $(n=2)$, Sjögren syndrome $(n=1)$ and scleroderma $(n=2)$.

${ }^{\mathrm{d}}$ Asthma $(n=2)$, vasculitis $(n=1)$. 
biopsy samples were analyzed from a patient with IPF. Lung tissue samples were washed with ice-cold phosphate-buffered saline (PBS) and cut into approximately $1 \mathrm{~mm}^{3}$ pieces. The pieces were placed in BAL cell medium (BALM, minimum essential medium Eagle, $\alpha$-modification (Sigma, Steinheim, Germany) containing 13\% fetal bovine serum (FBS-500, PromoCell, Heidelberg, Germany), $10 \mathrm{mM}$ 4-2-hydroxyethyl)-1-piperazine-ethanesulfonic acid (HEPES, Sigma), $100 \mathrm{U} / \mathrm{ml}$ penicillin (Sigma), $100 \mu \mathrm{g} / \mathrm{ml}$ streptomycin ( $10 \mathrm{mg} /$ $\mathrm{ml}$, Sigma), $2.5 \mu \mathrm{g} / \mathrm{ml}$ amphotericin B (Sigma) and $2 \mathrm{mM}$ L-glutamine (Sigma)) into the cell culture flasks and the cells were allowed to attach for 1 day. The remaining tissue pieces were washed away and the cells were cultured as BAL-derived cells.

\section{Cell Culture}

The BAL fluid was filtered through $100 \mu \mathrm{m}$ mesh and centrifuged ( $300 \mathrm{~g}$ for $10 \mathrm{~min}$ at room temperature). Cells were plated at a density of 40000 cells per $\mathrm{cm}^{2}$ and cultured in BALM. After 3 weeks' cultivation, fibroblastic cell colonies were counted, passaged $(5 \mathrm{mg} / \mathrm{ml}$ trypsin $-2 \mathrm{mg} / \mathrm{ml}$ EDTA (Sigma)) and plated at a density of 2500 cells per $\mathrm{cm}^{2}$. For testing the cell culture method, the samples from various passages ${ }^{2,4,6}$ were analyzed from the sample of a patient with allergic alveolitis and from two passages ${ }^{1,5}$ from the sample of a patient with pulmonary damage after experiencing a drug reaction. See Supplementary data about the stability of cell phenotype studied by electron microscope and western blot (Supplementary Figures 1-2 in online supplement).

\section{Antibodies}

Primary and secondary antibodies are shown in Table 2. Mouse and rabbit isotype controls (Zymed, Invitrogen, Carlsbad, CA, USA) were used as negative controls.

\section{Transmission Electron Microscope}

The specimen preparation has been previously described. ${ }^{14}$ The samples of every patient were analyzed. Cells were fixed in $1 \%$ glutaraldehyde and 4\% PFA mixture in $0.01 \mathrm{M}$ PBS for $10 \mathrm{~min}$. The cells were scraped off, pelleted and fixation was continued for $1 \mathrm{~h}$. The pellet was immersed in 2\% Agarose (in $\mathrm{dH}_{2} \mathrm{O}$ ) and postfixed in $1 \%$ osmium tetroxide in $\mathrm{dH}_{2} \mathrm{O}$ for $30 \mathrm{~min}$. The specimen were dehydrated in acetone and immersed in Epon LX112 (Ladd Research Industries, Vermont, USA)-acetone. Thin sections $(80 \mathrm{~nm})$ were cut with Leica Ultracut UCT ultramicrotome (Leica Microsystems, Vienna, Austria) and stained with uranyl acetate and lead citrate and examined in a Philips CM 100 TEM (FEI, Eindhoven, The Netherlands) equipped with a Morada digital camera (Olympus Soft Imaging System, Münster, Germany).

\section{Quantitation of TEM}

The interest of the ultrastructural study was to characterize the occurrence and morphology of the cell surface structure, that is, the FNX. The analysis was based on the FNX classifications proposed by Singer et al. ${ }^{5}$

The TEM findings of cultured cells of each patient were quantified systematically as follows: amount of actin filaments as low $(+)$, moderate $(++)$ or strong $(+++)$;

Table 2 Antibodies used in immunoelectron microscopy and western blot

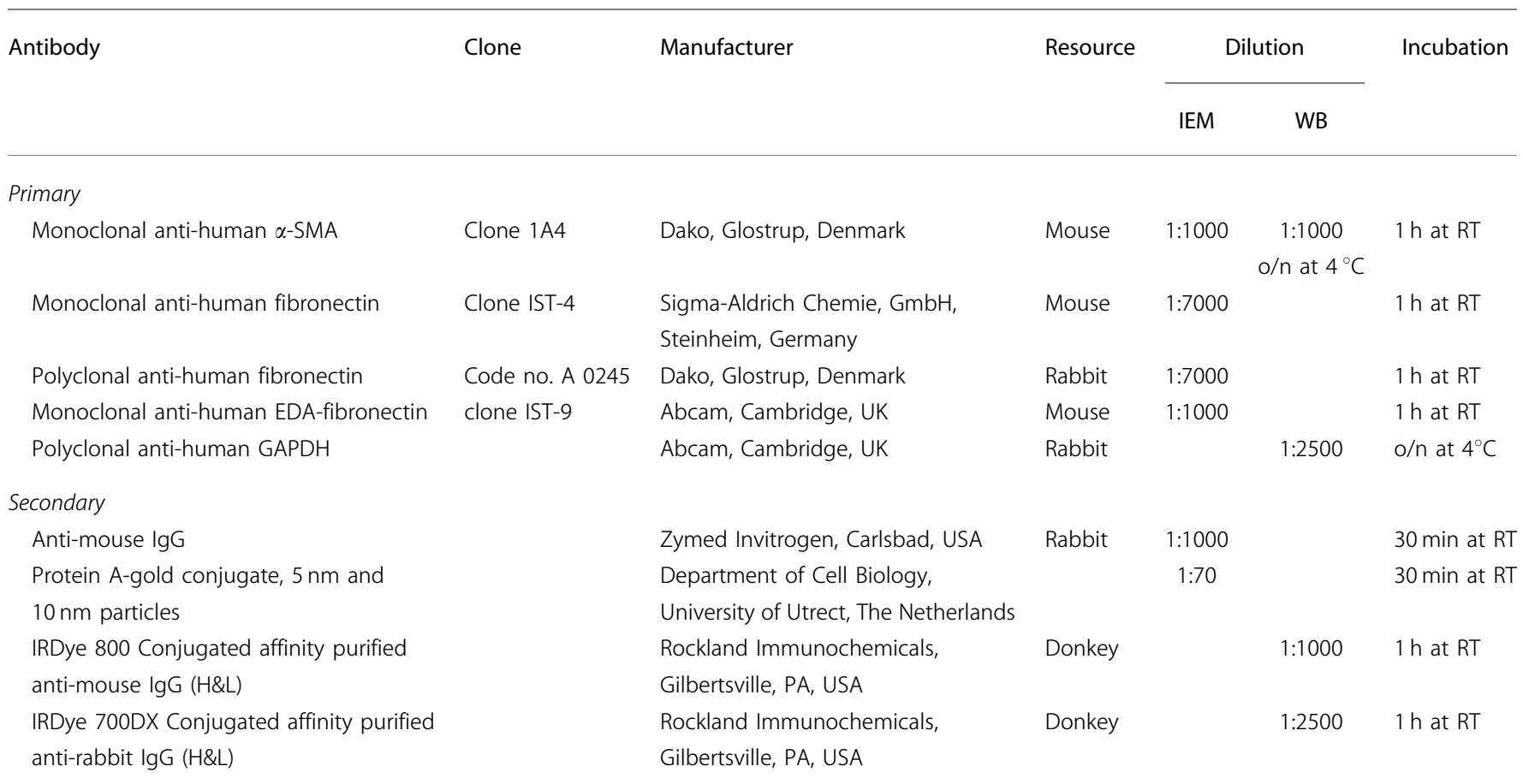


amount of extracellular component of FNX as low $(+)$, moderate $(++)$ or strong $(+++)$; amount of extracellular matrix (ECM) surrounding cells as low $(+)$, moderate $(++)$ or strong $(+++)$; type of FNX as tandem, plaque or track-like, and focal densities, dilated rough endoplasmic reticulum (rER), adherens- and gap-type junctions as numbers of positive cases (in parentheses, percentage value). TEM findings of each sample were analyzed from a $500 \mu \mathrm{m}^{2}$ area blindly without any knowledge of the diagnosis. Examples of grading the expression of actin and ECM are shown in supplementary material (Supplementary Figures 3 and 4 in online supplement). The frequency of the extracellular component of FNX was estimated as follows: negative, no FNX structure was found; low, FNX was found in $10 \%$ of the cells; moderate, FNX was found in $30 \%$ of the cells; and strong, FNX was found in $60 \%$ of the cells.

Two authors (HMK, RTS) evaluated the TEM findings separately and the agreement coefficient was established according to Cohen's kappa statistics as described and Fisher's exact test. ${ }^{16}$ There was almost perfect agreement between the evaluation by the two investigators $(P<0.001$, Fisher's exact test; kappa coefficient $=0.95$ ).

\section{Immunoelectron Microscope}

The specimen preparation has been previously described. ${ }^{14}$ Cells were fixed in 4\% PFA in $0.1 \mathrm{M}$ PBS with $2.5 \%$ sucrose. After pelleting, the cells were immersed in $12 \%$ gelatin in PBS and kept on ice for $30 \mathrm{~min}$ and then immersed in $2.3 \mathrm{M}$ sucrose in PBS for $24 \mathrm{~h}$. Ultrathin sections were cut with a Leica EM UC6 cryoultramicrotome. For immunolabelings, ultrathin sections were incubated in $0.1 \%$ glycine + PBS followed by incubation in $1 \%$ bovine serum albumin (BSA) in PBS. All washes and antibody dilutions were performed in PBS $+1 \%$ BSA. With the monoclonal antibody, the secondary antibody rabbit anti-mouse IgG was applied. The samples were incubated with protein A-gold conjugates $(10 \mathrm{~nm}$ for single labeling and for double labeling $10 \mathrm{~nm}$ and $5 \mathrm{~nm}$ particles were applied). ${ }^{17}$ Sections were embedded in methylcellulose and studied as described above.

\section{Quantitation of the Expression of $\alpha$-SMA and Fibronectin by IEM}

Four rectangles with areas of $0.26 \mu \mathrm{m}^{2}$ were diagonally marked from the upper left corner to the lower right corner of the image and gold particles were counted from each rectangle. The total area of quantitation was $10.4 \mu \mathrm{m}^{2}$ in each patient sample. The number of gold particles was counted. Values were compared with surgically operated uninvolved lung tissue-cultured fibroblasts, which were used as a control. The results were reported as relative protein expression in IEM.

\section{Cell Invasion}

The invasion capacity was defined by using Cultrex ${ }^{\circledR}$ Basement Membrane Extract Cell Invasion Assay (R\&D Systems,
Abingdon, UK) according to the manufacturer's instructions. Calcein-acetoxymethylester (calcein-AM) was used as a detector of cellular oxidative activity. Calcein-AM is a nonfluorescent, cell membrane permeable substance, which is converted by intracellular esterase reactions into calcein that is an anionic fluorescent form. Cells cultured in four replicate wells (50 000 cells per a well) in 96-well plates were incubated for $48 \mathrm{~h}$ at $37^{\circ} \mathrm{C} / 5 \% \mathrm{CO}_{2}$. The number of invaded cells was defined from the corresponding standard curve measured fluorometrically (Victor ${ }^{2}$, Wallac Oy, Turku, Finland) at the wavelengths of $\mathrm{A}_{485}$ (excitation) and $\mathrm{A}_{535}$ (emission) as the formation of calcein and the number of invaded cells was compared with the amount of plated cells to allow estimation of the invasion percentage. Human lung carcinoma cells A549 and human lung fibroblasts CCL-151 (both obtained from American Type Culture Collections) were used as controls to evaluate the variation between different assays.

\section{Western Blot}

Cells were lysed in lysis buffer $(50 \mathrm{mM}$ Tris pH 7.6, $0.1 \%$ Triton $\mathrm{X}-100,0.9 \% \mathrm{NaCl}, 0.2 \%$ sodium azide (Sigma), $0.1 \%$ deoxycholic acid (Sigma), 1x Protease Inhibitor Cocktail Tablet (Roche, Mannheim, Germany)) and centrifuged (10 000 r.p.m., $10 \mathrm{~min},+4^{\circ} \mathrm{C}$ ). The protein concentration of samples was determined by the microplate assay (DC Protein Assay Kit, Bio-Rad, UK) according to the manufacturer's instructions. In brief, $20-\mu \mathrm{g}$ aliquots in sample buffer $(0.1 \mathrm{M}$ Tris-HCl pH 6.8, 0.2 M dithiothreitol, 25\% glycerol, $1 \mathrm{mg} / \mathrm{ml}$ bromophenol blue, $4 \%$ SDS) were loaded on $12 \%$ SDS-PAGE with running buffer $(25 \mathrm{mM}$ Tris, $190 \mathrm{mM}$ glycine, $0.1 \%$ SDS) at $200 \mathrm{~V}$. After the electrophoresis, the proteins were transferred to nitrocellulose membrane (pore size $0.45 \mu \mathrm{m}$, Protran ${ }^{\circledR}$ Nitrocellulose Transfer Membrane, Schleicher and Schuell, BioScience, Dassel, Germany) with blotting buffer (30 mM Tris, $0.24 \mathrm{M}$ glycine, $20 \% \mathrm{EtOH}$ ) overnight and blocked in 5\% milk powder-PBST (PBS-0.1\% Tween 20) for $1 \mathrm{~h}$. After washing with PBST, the membrane was incubated with the primary antibody against human $\alpha$-SMA followed by the secondary antibody. Protein intensities were analyzed by Odyssey infrared imager (LI-COR Biosciences). Equal loading and transfer were confirmed by staining some membranes with $0.1 \%$ Ponceau $S$ in $5 \%$ acetic acid or by glyceraldehyde-3-phosphate dehydrogenase (GAPDH) detection. The data were reported as relative protein expression such that intensities detected for each sample were normalized against the intensity of the control sample on the same membrane. The same control sample that consisted of the cells cultured from one healthy patient's lung tissue sample was used on every gel/membrane to minimize the variation between different membranes.

\section{qRT-PCR of $\alpha$-SMA and Fibronectin}

Total RNA was extracted by RNeasy Mini Kit (Qiagen). The quality of RNA was tested by spectrophotometry with $1-\mu \mathrm{g}$ 
aliquots of RNA being reverse-transcribed using RevertAid ${ }^{\mathrm{TM}}$ First Strand Synthesis Kit (Fermentas). PCR amplification was performed in triplicate in a total volume of $25 \mu \mathrm{l}$ by using $\mathrm{iQ}^{\mathrm{TM}}$ SYBR Green Supermix (Bio-Rad, UK). Samples were processed for qRT-PCR with the using iQ 5 Multicolor RealTime PCR Detection System (Bio-Rad Laboratories) in the following conditions: $95^{\circ} \mathrm{C}$ for $3 \mathrm{~min}, 40$ cycles at $95^{\circ} \mathrm{C}$ for $10 \mathrm{~s}, 63^{\circ} \mathrm{C}$ for $10 \mathrm{~s}$ and $72{ }^{\circ} \mathrm{C}$ for $15 \mathrm{~s}$, and a final extension phase of $72{ }^{\circ} \mathrm{C}$ for $2 \mathrm{~min}$. The melt curve was created in the following way: 81 cycles at $55{ }^{\circ} \mathrm{C}$ for $30 \mathrm{~min}$. Relative gene expressions of fibronectin and $\alpha$-SMA were quantified by using the $2^{-\Delta \Delta \mathrm{T}}$ Livak method ${ }^{18}$ in which mRNA expression was normalized to the reference gene (human GAPDH) and compared with the expression of a control sample. The cells cultured from an apparently healthy lung tissue sample of one patient were used as a control sample and the results are shown as relative values as compared to that control sample. Primers used in qRT-PCR reactions were as follows: human fibronectin forward primer, 5'-CCTCGAAGAGCAAGAGG CAG-3', reverse primer, 5'-GCTTCAGGTTTACTCTCGCA$3^{\prime}$, human $\alpha$-SMA: forward primer, $5^{\prime}$ - GCAGCCCAGCCAA GCACTGT- $3^{\prime}$, reverse primer, $5^{\prime}$-TGGGAGCATCGTCCCC AGCA- $3^{\prime}$ and human GAPDH (hGAPDH) was used as a reference gene with following primers: forward primer, $5^{\prime}$-GAGTCAACGGATTTGGTCGT- ${ }^{\prime}$, reverse primer $5^{\prime}$-GAC AAGCTTCCCGTTCTCAG-3'.

\section{The Association of $\alpha$-SMA Expression with Cell Invasion}

We evaluated whether the amount of $\alpha$-SMA protein and/or mRNA was associated with invasive capacities of cells. The $\alpha$-SMA protein expressions in IEM and western blot and mRNA expression in qRT-PCR were compared with the invasive percentages in IPF, NSIP, CVD-ILD, asbestosis, sarcoidosis and in a drug reaction.

\section{Statistical Analysis}

Statistical analyses were performed by Statistical Package for the Social Sciences (SPSS; version 18.0.0, Chicago, IL) using $\chi^{2}$ test, Fisher's exact test, Mann-Whitney U-test, Pearson's correlation test, ANOVA or Kruskal-Wallis test. The normality of distributions was tested by Q-Q plot. Values of $P<0.05$ were considered as significant and indicated as ${ }^{*}<0.05,{ }^{* *}<0.01$ and ${ }^{* * *}<0.001$. No adjustments for multiple comparisons were done. ${ }^{19}$

\section{RESULTS TEM Findings}

BAL-derived cell populations were mixtures of fibroblasts and myofibroblasts (Figure 1 and Table 3). The myofibroblasts were often located as a group of a few cells. BALderived cells showed more moderate and strong expression of peripheral actin filaments than normal lung control cells $(P=0.026$, Fisher's exact test). A similar difference to control cells was also observed when analyzing the progressively behaving ILD, that is, IPF, NSIP, CVD-ILD and asbestosis as a group $(P=0.02$, Fisher's exact test $)$ and when analyzing both progressively behaving ILD, that is, IPF, NSIP, CVD-ILD and asbestosis together with those ILD, which are usually non-progressive, that is, sarcoidosis and allergic alveolitis as a group ( $P=0.031$, Fisher's exact test). In the latter group also the amount of ECM was higher than in the control samples $(P=0.042$, Fisher's exact test). Furthermore, we observed that cells derived from asbestosis patients expressed more actin filaments and IPF cells had a tendency to display more of these structures than normal lung fibroblasts $(P=0.048$ and $P=0.077$, respectively, Fisher's exact test). The expression of actin filaments correlated with the expression of the extracellular component of FNX $(P=0.001$, Fisher's exact test $)$ and with the amount of ECM $(P=0.001$, Fisher's exact test).

In each cell population, the majority of cells displayed a dilated rER. BAL cells that expressed moderately or strongly actin filaments had more dilated rER than cells expressing a low level of actin filaments $(P=0.028$, Fisher's exact test). Each cell line expressed the extracellular component of FNXs but at variable numbers and in distinct forms (Figure 1 and Table 3). All three kinds of FNXs according to Singer's classification $^{5}$ were observed, that is, (1) long and well-defined track-like FNX, (2) dense, cloud-like, short or fragmented plaque-like FNX, and (3) tandem-like FNXs, which were located at the end of cell extensions. The track-like FNX was the most common phenotype. The FNXs at the surfaces of the cells derived from IPF, NSIP, drug reaction and lung cancer were usually long and well defined in the sense that the other characteristic myofibroblastic features were also present (Table 3). The amount of extracellular component of FNX correlated with amount of ECM in the whole BAL data $(P<0.001$, Fisher's exact test $)$. Cells derived from patients with IPF, CVD-ILD, asbestosis and allergic alveolitis expressed plaque-like FNXs (Figure 1). Cells from patients with

Figure 1 Electron micrographs show the typical cellular features of BAL-originated cells in different lung disorders. (a) A normal fibroblast from a patient with sarcoidosis. RER (arrow) is not dilated and actin belt is not seen. (b) A typical myofibroblast from a patient with NSIP. Dilated rER (arrow) and a FNX are observed. The FNX is composed of dense intracellular actin belt (arrowhead) with focal densities and well-organized extracellular fibronectin bundle (asterisk) that is closely associated with the cell membrane. (c) A track-like FNX from a patient with IPF, in which the long fibronectin bundle (asterisk) longitudinally follows the cell membrane. The myofibroblast contains also an actin belt (arrowhead) in the cell periphery. (d) A myofibroblast from a patient with CVD-ILD shows plaque-like FNX, in which the extracellular bundle is cloud-like (asterisk). Actin belt and dilated rER are also observed. (e) A cell from a patient with a drug reaction exhibits tandem-like FNX, in which the extracellular filament bundle (asterisk) is localized at the end of a cellular extension. The actin belt (arrowhead) is seen in the contact site. (f) Adherens-type junction in cells is visible from a patient with CVD-ILD. Dense actin belts (arrowhead) and dilated rER (arrow) are clearly seen. 


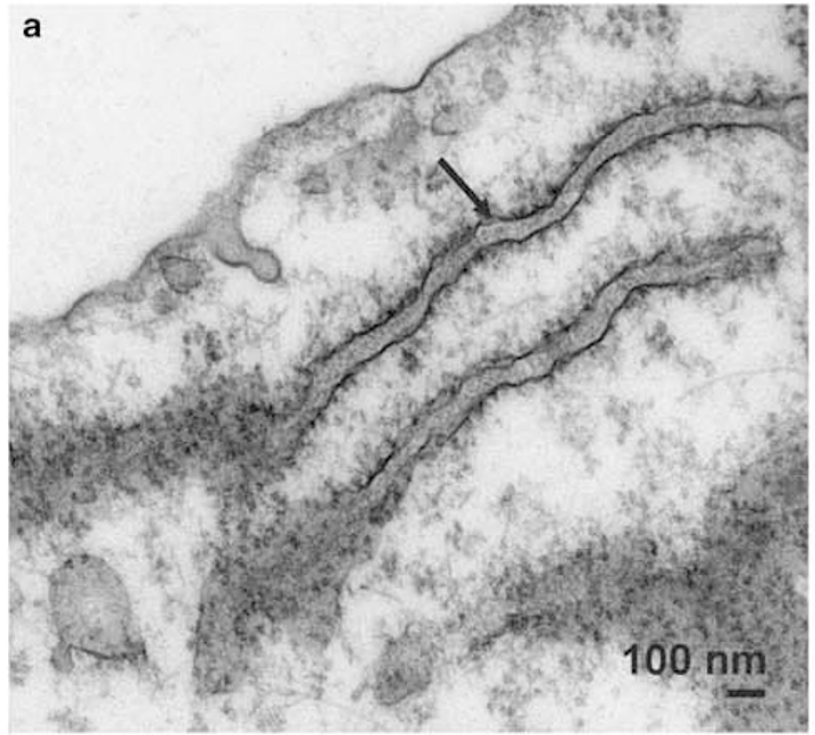

b
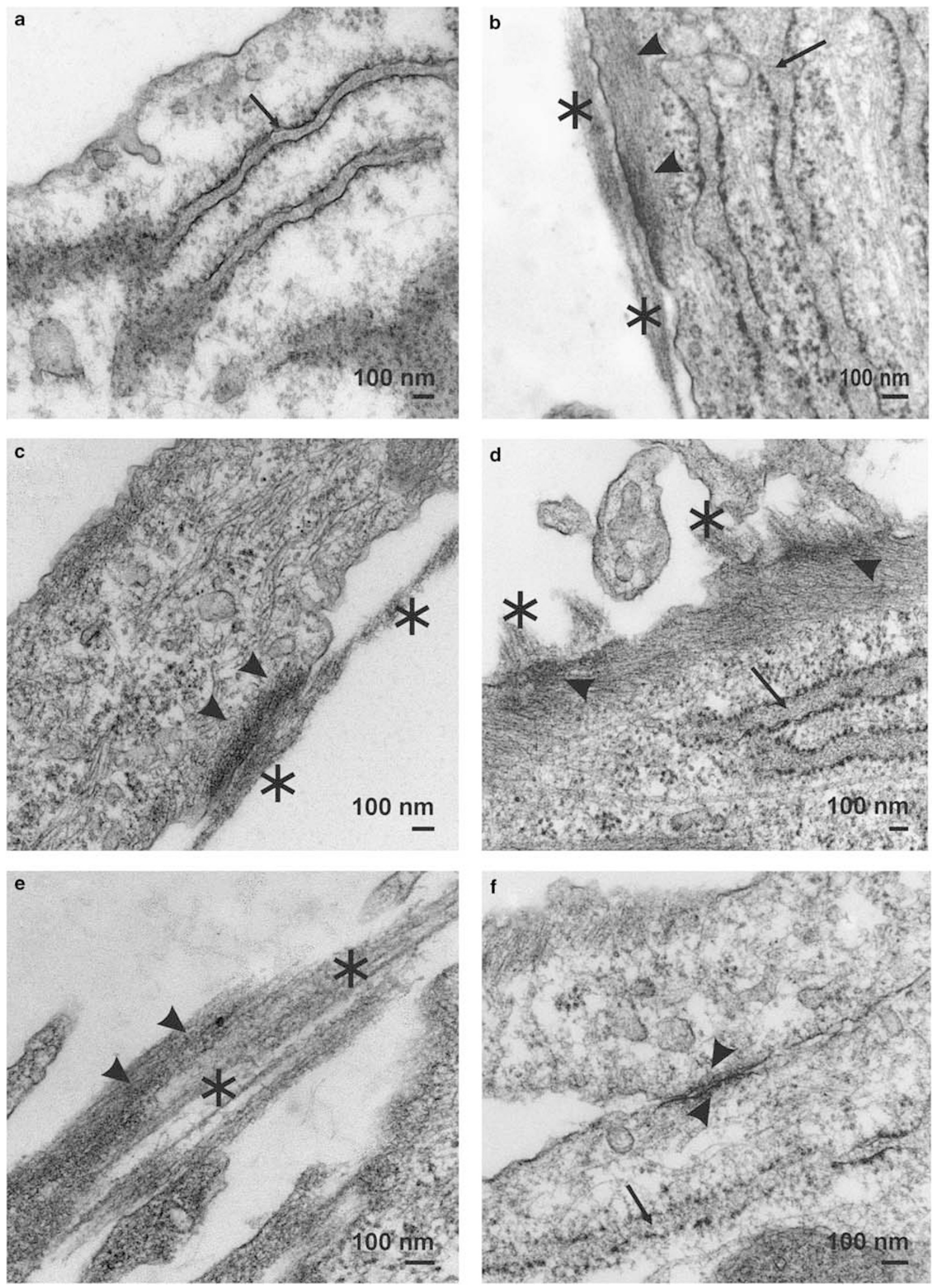
asbestosis and sarcoidosis expressed fragmentary and short FNX structures, and myofibroblasts were rarely found. Tandem-like FNX was rarely observed, but cells from the patients with a drug reaction expressed it most frequently (Figure 1).

Adherens-type junctions were observed in some cells cultured from the patients with IPF, NSIP, CVD-ILD, asbestosis, sarcoidosis, allergic alveolitis and a drug reaction. Gap-type junctions were not observed. The amount of ECM filaments varied in the different lung disease-derived cell populations. In general, BAL cells expressed more ECM $(P=0.049$, Fisher's exact test) and had a tendency to have more adherens junction-type structures $(P=0.069$, Fisher's exact test) than control cells. In particular, the cells cultured from patients with sarcoidosis expressed more ECM $(P=0.048$, Fisher's exact test) and adherens junction-type structures $(P=0.033$, Fisher's exact test $)$ than control cells.

\section{IEM Findings}

IEM confirmed the TEM findings, that is, the presence of $\alpha$ SMA in intracellular filaments and fibronectin in the extracellular space (Figure 2). Cells cultured from patients with IPF, asbestosis, lung cancer and drug reaction showed intensively $\alpha$-SMA and fibronectin labeling. The $\alpha$-SMA labeling was localized in the intracytoplasmic filaments on the edges of cells. Cells from the patients with NSIP, sarcoidosis and allergic alveolitis displayed low expression of $\alpha$-SMA and high expression of fibronectin. Cells from CVD-ILD expressed a considerable amount of $\alpha$-SMA but a low level of fibronectin.

The expression of extra domain A (ED-A) fibronectin isoform was analyzed in selected cases (Figure 3). The ultrastructural localization of ED-A fibronectin was similar to that of fibronectin.

\section{TEM and IEM Findings of Lung Tissue Samples as Controls}

Cells cultured from four peripheral lung tissues were a mixture of myofibroblasts and fibroblasts and exhibited similar ultrastructural features as the cells cultured from BAL, that is, part of the cells were fibroblasts and some of them were myofibroblasts with intracellular actin filaments, dilated rER, extracellular filament bundles and adherens junctions. The TEM findings were confirmed by IEM, which revealed that some of the cells were positive for $\alpha$-SMA and fibronectin similarly to BAL-cultured cells. The analysis of the cells from the IPF patient indicated that the TEM and IEM findings were similar in cells cultured from both BAL and lung tissue (Figure 4).

\section{Quantitation of the Expression $\alpha$-SMA and Fibronectin by IEM}

Figure 5 shows examples of quantitation of $\alpha$-SMA and fibronectin expression. Ten representative images at a magnification of 46000 were taken for each patient. The amounts of $\alpha$-SMA and fibronectin protein were quantitated by counting the number of gold labels and compared this with the numbers of the control cells. The $\alpha$-SMA and fibronectin expressions were highest in the cells derived from patients suffering from IPF, asbestosis, CVD-ILD and lung cancer (Figure 6). The cells from patients with IPF $(P=0.019$, Mann-Whitney $U$-test $)$ or asbestosis $(P=0.050$, MannWhitney $U$-test) expressed more $\alpha$-SMA than control cells and a similar difference was found between BAL-derived cells and control cells $(P=0.017$, Mann-Whitney $U$-test $)$.

BAL cells derived from ILD, that is, IPF, NSIP, CVD-ILD, asbestosis, sarcoidosis and allergic alveolitis had more $\alpha$-SMA labeling than the control cells cultured from normal lung tissue $(P=0.023$, Mann-Whitney $U$-test $)$. A similar difference was observed also when analyzing the progressively behaving ILD, that is, IPF, NSIP, CVD-ILD and asbestosis as a group $(P=0.022$, Mann-Whitney $U$-test $)$.

\section{Cell Invasion}

The invasive capacity of cells varied in different lung disorders $(0.74 \%$, s.d. 0.41$)$ (Figure 7). Cells cultured from BAL fluid exhibited rather similar invasive capacities as lung cancer cells A549 (0.76\%, s.d. 0.38, not shown in Figure 7) and lung fibroblasts CCL-151 (0.46\%, s.d. 0.04, not shown in Figure 7). Cells cultured from BAL of the IPF patients showed the highest invasive capacity $(0.86 \%$, s.d. 0.17$)$. The invasive capacity of the cells cultured from the patients with IPF was higher than that of those from patients with other lung diseases $(P=0.036$ by Mann-Whitney $U$-test). When comparing IPF with the other disease groups, the cells cultured from IPF revealed a significantly higher invasive capacity than those from subjects with asbestosis $(P=0.027$ by Mann-Whitney $U$-test). The invasive capacity of IPF cells was also higher than those from specimens from patients suffering from sarcoidosis $(P=0.068$ by Mann-Whitney $U$ test) and a drug reaction $(P=0.064$ by Mann-Whitney $U$ test), although the differences were not statistically significant.

\section{Western Blot}

Western blot data were mostly in line with the IEM observations showing that $42 \mathrm{kDa}$-sized $\alpha$-SMA protein was variably expressed in the different lung disorders (Figure 8). Cells derived from patients with sarcoidosis and allergic alveolitis expressed high quantities of $\alpha$-SMA although the differences between groups were not statistically significant. The $\alpha$-SMA expression was moderate in cells derived from IPF, NSIP, CVD-ILD, vasculitis and asthma.

\section{qRT-PCR of $\alpha$-SMA and Fibronectin}

The relative expression of $\alpha$-SMA mRNA was heterogeneous in the different diseases (Figure 9). In the whole study group, the $\alpha$-SMA mRNA expression weakly correlated with $\alpha$-SMA protein expressions in IEM $(r=0.600, P=0.000)$ and protein expression in western blot $(r=0.453, P=0.002)$. In cells cultured from the patients with IPF, the $\alpha$-SMA mRNA expression correlated with $\alpha$-SMA protein expression in western blot ( $r=0.908, P=0.005$ Pearson's correlation test). 


\begin{tabular}{|c|c|c|c|c|c|c|c|c|c|c|c|c|}
\hline & \multicolumn{12}{|c|}{ Lung disease ( $n) /$ number of positive cases (\%) } \\
\hline & IPF (11) & NSIP (7) & $\begin{array}{l}\text { CVD-ILD } \\
(7)\end{array}$ & $\begin{array}{l}\text { Asbestosis } \\
\text { (5) }\end{array}$ & $\begin{array}{l}\text { Sarcoi- } \\
\text { dosis (6) }\end{array}$ & $\begin{array}{l}\text { Allergic } \\
\text { alveolitis (3) }\end{array}$ & $\begin{array}{c}\text { Drug } \\
\text { reaction (4) }\end{array}$ & $\begin{array}{c}\text { Lung } \\
\text { cancer (2) }\end{array}$ & Normal (1) & RB-ILD (1) & Other (4) & $\begin{array}{l}\text { Normal lung } \\
\text { control }(4)^{\mathrm{a}}\end{array}$ \\
\hline \multicolumn{13}{|l|}{ Actin filaments ${ }^{\mathrm{b}, \mathrm{c}}$} \\
\hline+ & $4(36 \%)$ & $3(43 \%)$ & $3(43 \%)$ & $1(20 \%)^{d}$ & $2(33 \%)$ & $2(67 \%)$ & $2(50 \%)$ & $1(50 \%)$ & $1(100 \%)$ & $0(0 \%)$ & $0(0 \%)$ & $4(100 \%)$ \\
\hline++ & $7(64 \%)$ & $3(43 \%)$ & $3(43 \%)$ & $4(80 \%)^{d}$ & $3(50 \%)$ & $1(33 \%)$ & $2(50 \%)$ & $0(0 \%)$ & $0(0 \%)$ & $1(100 \%)$ & $2(50 \%)$ & $0(0 \%)$ \\
\hline+++ & $0(0 \%)$ & $1(14 \%)$ & $1(14 \%)$ & $0(0 \%)^{d}$ & $1(17 \%)$ & $0(0 \%)$ & $0(0 \%)$ & $1(50 \%)$ & $0(0 \%)$ & $0(0 \%)$ & $2(50 \%)$ & $0(0 \%)$ \\
\hline \multicolumn{13}{|c|}{ Extracellular component of fibronexus, } \\
\hline- & $1(9 \%)$ & $0(0 \%)$ & $0(0 \%)$ & $0(0 \%)$ & $0(0 \%)$ & $0(0 \%)$ & $0(0 \%)$ & $0(0 \%)$ & $0(0 \%)$ & $0(0 \%)$ & $0(0 \%)$ & $0(0 \%)$ \\
\hline+ & $6(55 \%)$ & $3(43 \%)$ & $6(86 \%)$ & $4(80 \%)$ & $4(67 \%)$ & $2(67 \%)$ & $4(100 \%)$ & $1(50 \%)$ & $1(100 \%)$ & $1(100 \%)$ & $0(0 \%)$ & $2(50 \%)$ \\
\hline++ & $3(27 \%)$ & $2(29 \%)$ & $1(14 \%)$ & $1(20 \%)$ & $0(0 \%)$ & $1(33 \%)$ & $0(0 \%)$ & $0(0 \%)$ & $0(0 \%)$ & $0(0 \%)$ & $3(75 \%)$ & $2(50 \%)$ \\
\hline+++ & $1(9 \%)$ & $2(29 \%)$ & $0(0 \%)$ & $0(0 \%)$ & $2(33 \%)$ & $0(0 \%)$ & $0(0 \%)$ & $1(50 \%)$ & $0(0 \%)$ & $0(0 \%)$ & $1(25 \%)$ & $0(0 \%)$ \\
\hline \multicolumn{13}{|l|}{$E C M^{f, c, e}$} \\
\hline- & $3(27 \%)$ & $2(29 \%)$ & $2(29 \%)$ & $2(40 \%)$ & $1(17 \%)^{9}$ & $1(33 \%)$ & $1(25 \%)$ & $1(50 \%)$ & $1(100 \%)$ & $1(100 \%)$ & $0(0 \%)$ & $4(100 \%)$ \\
\hline+ & $7(64 \%)$ & $2(29 \%)$ & $4(57 \%)$ & $3(60 \%)$ & $4(67 \%)^{9}$ & $2(67 \%)$ & $3(75 \%)$ & $0(0 \%)$ & $0(0 \%)$ & $0(0 \%)$ & $2(50 \%)$ & $0(0 \%)$ \\
\hline++ & $0(0 \%)$ & $2(29 \%)$ & $1(14 \%)$ & $0(0 \%)$ & $1(17 \%)^{9}$ & $0(0 \%)$ & $0(0 \%)$ & $1(50 \%)$ & $0(0 \%)$ & $0(0 \%)$ & $2(50 \%)$ & $0(0 \%)$ \\
\hline+++ & $1(9 \%)$ & $1(14 \%)$ & $0(0 \%)$ & $0(0 \%)$ & $0(0 \%)^{9}$ & $0(0 \%)$ & $0(0 \%)$ & $0(0 \%)$ & $0(0 \%)$ & $0(0 \%)$ & $0(0 \%)$ & $0(0 \%)$ \\
\hline Focal densities & $10(91 \%)$ & $7(100 \%)$ & 7 (100\%) & $5(100 \%)$ & $6(100 \%)$ & $3(100 \%)$ & $4(100 \%)$ & $2(100 \%)$ & $0(0 \%)$ & $1(100 \%)$ & $4(100 \%)$ & $3(75 \%)$ \\
\hline Dilated rough ER & $7(64 \%)$ & $7(100 \%)$ & $6(86 \%)$ & $3(60 \%)$ & $6(100 \%)$ & $2(67 \%)$ & $3(75 \%)$ & $2(100 \%)$ & $1(100 \%)$ & $0(0 \%)$ & $4(100 \%)$ & $4(100 \%)$ \\
\hline Adherens junction-type & $8(73 \%)$ & $4(57 \%)$ & $6(86 \%)$ & $3(60 \%)$ & $6(100 \%)^{h}$ & $3(100 \%)$ & $3(75 \%)$ & $1(50 \%)$ & $1(100 \%)$ & $1(100 \%)$ & $2(50 \%)$ & $1(25 \%)$ \\
\hline Gap junction-type & $0(0 \%)$ & $0(0 \%)$ & $0(0 \%)$ & $0(0 \%)$ & $0(0 \%)$ & $0(0 \%)$ & $0(0 \%)$ & $0(0 \%)$ & $0(0 \%)$ & $0(0 \%)$ & $0(0 \%)$ & $0(0 \%)$ \\
\hline Track-like & $10(91 \%)$ & $7(100 \%)$ & $7(100 \%)$ & $5(100 \%)$ & $6(100 \%)$ & $3(100 \%)$ & $4(100 \%)$ & $2(100 \%)$ & $1(100 \%)$ & $1(100 \%)$ & $4(100 \%)$ & $4(100 \%)$ \\
\hline Tandem-like & $1(9 \%)$ & $2(29 \%)$ & $0(0 \%)$ & $0(0 \%)$ & $1(17 \%)$ & $1(33 \%)$ & $1(25 \%)$ & $1(50 \%)$ & $0(0 \%)$ & $0(0 \%)$ & $0(0 \%)$ & $0(0 \%)$ \\
\hline Plaque-like & $1(9 \%)$ & $0(0 \%)$ & $1(14 \%)$ & $0(0 \%)$ & $0(0 \%)$ & $1(33 \%)$ & $2(50 \%)$ & $0(0 \%)$ & $0(0 \%)$ & $0(0 \%)$ & $1(25 \%)$ & $0(0 \%)$ \\
\hline
\end{tabular}

Abbreviations: CVD-ILD, collagen-vascular disease associated with interstitial lung disease; ECM, the deposition of extracellular matrix within cell populations; ER, endoplasmic reticulum; IPF, idiopathic pulmonary fibrosis; NSIP, nonspecific interstitial pneumonia; RB-ILD, respiratory bronchiolitis associated interstitial lung disease.

${ }^{\mathrm{a}}$ Control cells of normal lung have been cultured from peripheral lung tissues of patients whose have been operated for lung cancer.

bAL cells show more moderate and strong expression of actin filaments than normal lung control cells $(P=0.026$, Fisher's exact test).

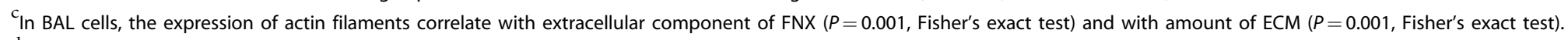

${ }^{\mathrm{d}}$ Asbestosis cells express more actin filaments than normal lung control cells $(P=0.048$, Fisher's exact test).

In BAL cells, the expression of extracellular component of FNX correlates with amount of ECM $(P<0.001$, Fisher's exact test).

BAL cells express more amount of ECM than normal lung control cells $(P=0.049$, Fisher's exact test).

${ }^{\mathrm{g}}$ Sarcoidosis cells express more amount of ECM than normal lung control cells $(P=0.048$, Fisher's exact test).

${ }^{\mathrm{h}}$ Sarcoidosis cells express more adherens junction structures than normal lung control cells $(P=0.033$, Fisher's exact test).

Numbers indicate the cases that express certain features (percentage in parenthesis).

Classification: - not found, + low, ++ moderate, +++ strong expression (see criteria for grading of expressions in Materials and methods section and online supplement).

Other = asthma $(n=2)$, COPD/emphysema $(n=1)$, vasculitis $(n=1)$. 

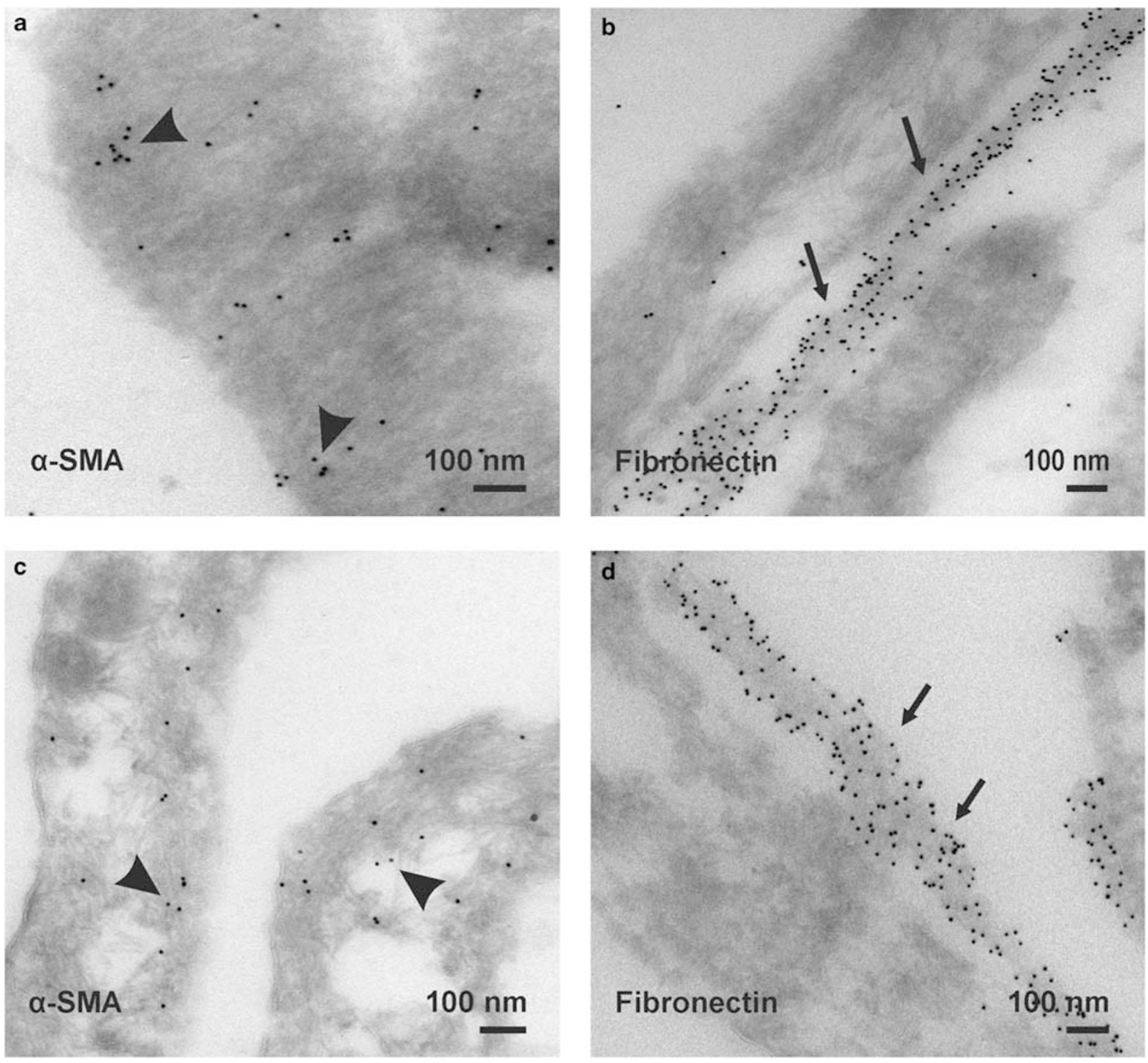

Figure 2 Immunoelectron micrographs showing $\alpha$-SMA (arrowhead) and fibronectin (arrow) localization. (a, b) Cells from an IPF patient show an intensive labeling of $\alpha$-SMA on the peripheral actin filaments. Fibronectin bundles are well-organized, long and the most commonly in the track-like orientation. (c, d) Cells from the patient with asbestosis express abundantly $\alpha$-SMA and fibronectin. (e, f) The $\alpha$-SMA labeling is sparse in the cytoplasm in the cells cultured from the patient with NSIP. The fibronectin bundle is narrow and short. (g, h) Cells from the patient with sarcoidosis showing sparse $\alpha$-SMA expression; the fibronectin bundle is fragmented.

In NSIP cells, the $\alpha$-SMA mRNA expression correlated with $\alpha$-SMA protein expression in IEM $(r=0.975, P<0.001$ Pearson's correlation test). Despite the right skewed distributions, ANOVA analyses were able to reveal significant differences between the disease groups in mRNA expressions of $\alpha$-SMA $(P=0.005)$ and fibronectin $(P=0.001)$. Post-hoc test of Dunnett showed that cells from allergic alveolitis expressed more fibronectin mRNA $(P=0.001)$ than IPF cells.

The Association of $\alpha$-SMA Expression with Cell Invasion Invasion of IPF cells showed a positive correlation with $\alpha$-SMA mRNA $(r=0.960, P=0.01$ Pearson's correlation test) and protein expression $(r=0.988, P=0.002$ Pearson's correlation test) (Figure 10). The invasive capacity of NSIP cells exhibited a positive correlation with $\alpha$-SMA mRNA expression $(r=0.998$, $P=0.036$ Pearson's correlation test) whereas that of sarcoidosis revealed a positive correlation with $\alpha$-SMA protein expression ( $r=0.851, P=0.032$ Pearson's correlation test). The invasive capacity of the cells of patients experiencing a drug reaction showed positive correlation with $\alpha$-SMA mRNA expression $(r=0.992, P=0.008$ Pearson's correlation test). The cells exhibiting moderate or strong amount of actin filaments displayed more active invasion than the cells with low amount of intracellular actin filaments $(P=0.002$, Fisher's exact test). 

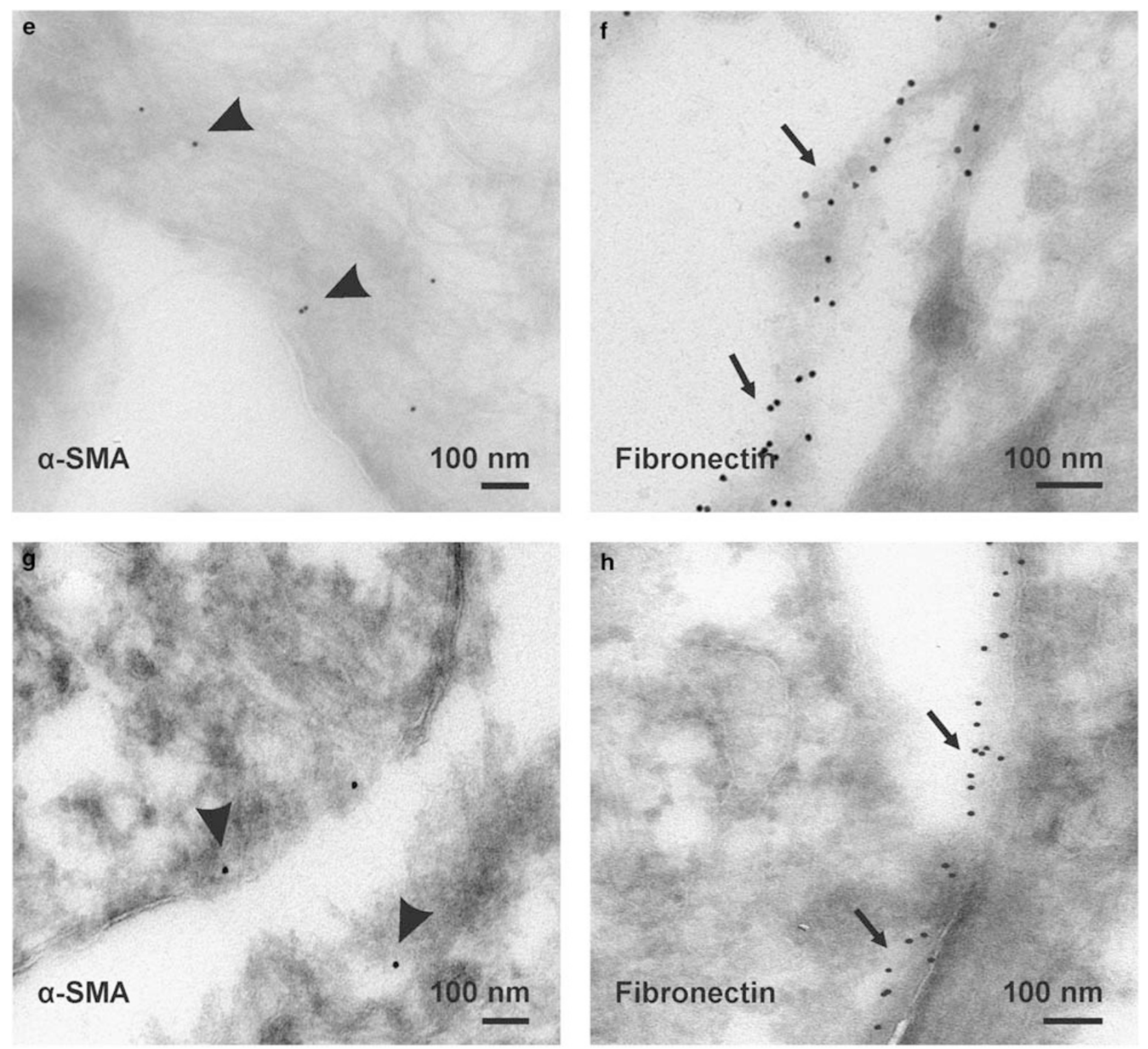

Figure 2 Continued.

\section{DISCUSSION}

This study demonstrates the ultrastructure and invasive capacities of BAL-cultured cells from a relatively large patient material. Our study has several implications. This is the first study that has used both TEM and IEM methods in the ultrastructural characterization of fibroblasts and myofibroblasts cultured from diagnostic BAL fluid samples. Second, this is the most multifaceted study material of BAL-cultured cells comprising over 10 different lung diseases. Although Badri et $a l^{20}$ have collected a study population composed of 405 BAL samples obtained from 162 lung transplant recipients, they focused on studying bronchiolitis obliterans syndrome. Moreover, as far as we are aware, no other group would have analyzed diagnostic samples with such small volumes of BAL fluids as used in this study. The number of

the patients, however, in each disease group is quite low, which hinders the statistical evaluation of the results.

A recently published study showed heterogeneity of stromal cells in fibrotic lung of both human and mouse, a finding that is supported by the results of our study revealing ultrastructurally and functionally variable stromal cells in human lung. ${ }^{21}$ That particular study was able to exclude pericytes and two types of epithelial cell populations as the origin of myofibroblasts. We observed that the amount of intracellular actin filament by TEM was higher in the cells cultured from the patients with ILD than in control samples representing normal lung tissue. Moreover, the amount of actin correlated with the extracellular component of FNX and the amount of ECM. Further, by IEM studies IPF and asbestosis revealed the highest amount of labels of $\alpha$-SMA 

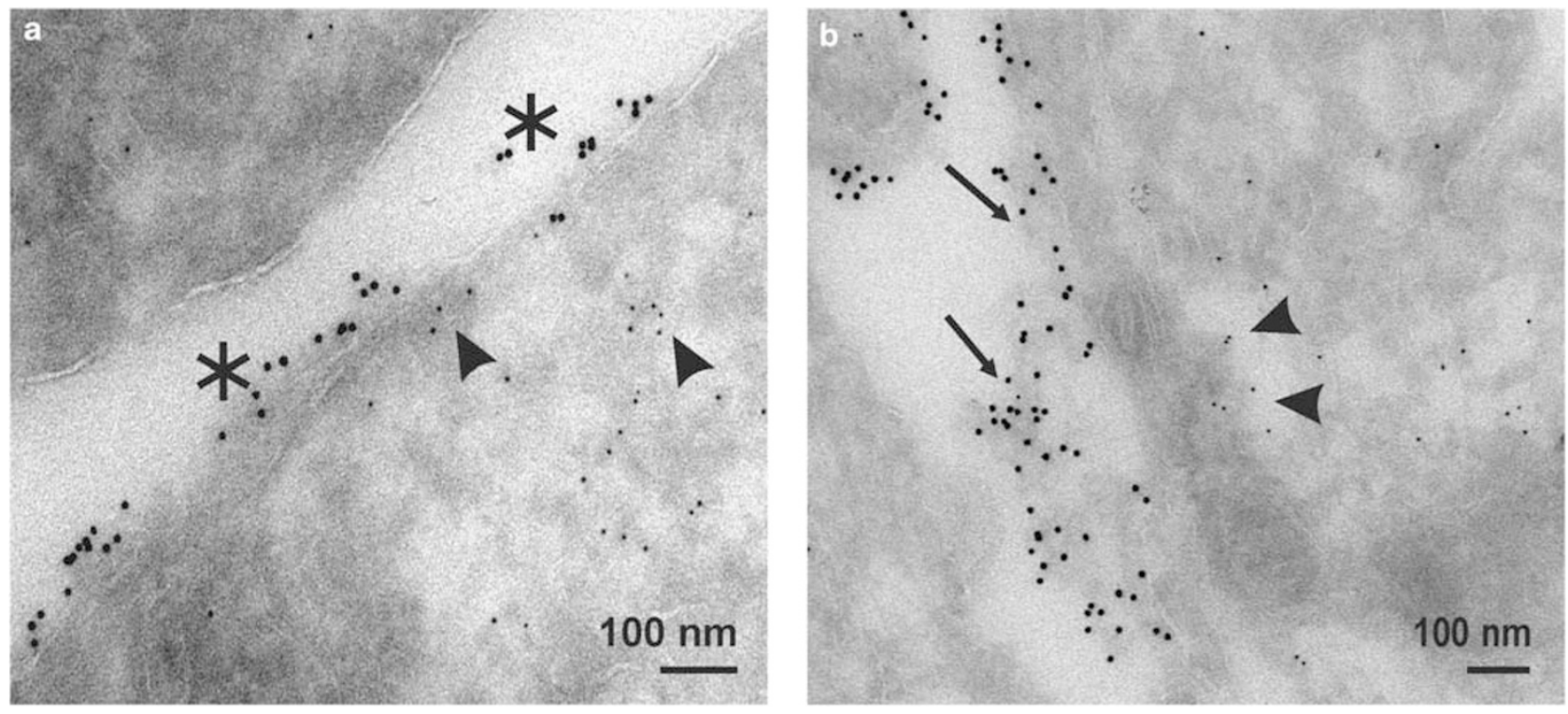

Figure 3 Colocalization of $\alpha$-SMA (arrowhead) and fibronectin (asterisk) and $\alpha$-SMA and ED-A fibronectin (arrow) in cells derived from IPF patients. (a) Represents colocalization of $\alpha$-SMA $(5 \mathrm{~nm}$ gold particles) and fibronectin ( $10 \mathrm{~nm}$ gold particles). Intracellular actin filaments beneath the cell membrane are rich in $\alpha$-SMA. (b) Shows colocalization of intracellular $\alpha$-SMA ( $5 \mathrm{~nm}$ gold particles) and extracellular ED-A isoform (10 nm gold particles). The expressions of fibronectin and fibronectin ED-A isoforms are similar.

and fibronectin. As far as we are aware, there are no previous studies that have compared the structure of myofibroblasts of the patients with various ILD by using TEM or IEM. Furthermore, earlier published studies have not analyzed as many different lung diseases as examined here, which revealed that in several ILD such as asbestosis, sarcoidosis and allergic alveolitis, ultrastructurally typical myofibroblasts are present. By using TEM and IEM, it is possible to investigate accurately structures of single cell that are not possible with western blotting, PCR and the other biochemical methods, which are commonly used. TEM and IEM facilitate in a unique way studies on heterogeneous cell populations, in which some certain cell type, such as a myofibroblast, is believed be in the leading pathogenetic role.

In their review article on myofibroblasts written a decade ago Hinz and Gabbiani ${ }^{22}$ stated that virtually nothing is known about the mechanisms of adherens junction formation, molecular nature and function, as most studies on adherens junctions had been performed using other cell types, like epithelial and endothelial cells. Those same authors $^{23}$ used light microscopy to confirm that the formation of the adherens junction coincided with myofibroblast differentiation in rat wound granulation. In our TEM study, adherens-type cell junctions were visible in the cells cultured from patients with different diseases such as IPF, NSIP, CVDILD, asbestosis, sarcoidosis, allergic alveolitis and drug reaction. We did not observe any gap junctions, which have been postulated to be typical of myofibroblasts. ${ }^{24}$ The finding that adherens-type junctions are present in myofibroblasts is in line with the results of previous studies. ${ }^{14,25}$ Although the existence of adherens junctions in each case of our study was variable, no statistically significant difference was observed between different diseases. On the other hand, there was a more frequent occurrence of adherens junctions in BALcultured diseased cells than in cells derived from normal lung. The evaluation of the differences between various diseases would need more patients in each study group, which would be possible in the future with this kind of study protocol utilizing BAL fluid samples taken from diagnostic purposes.

In our study, the cells cultured from IPF patients had a greater invasive capacity than the cells cultured from the patients with other types of lung diseases. To our knowledge, there are no previous published studies that have compared the invasive properties of fibroblastic cells in patients with various fibrotic and ILDs. A previous study showed that fibroblasts from the patients with IPF invaded spontaneously basement membranes unlike normal lung fibroblasts. ${ }^{26}$ Another recent study showed that knockdown of $\beta$-arrestin2 in fibroblasts from IPF patient attenuated the invasive phenotype. ${ }^{27}$ We also observed that the cells exhibiting moderate or strong amount of actin filaments had more active invasion than the cells with low amount of intracellular actin filaments and that the invasion of the cells cultured from the patients with IPF correlated positively with both mRNA and protein levels of $\alpha$-SMA. Also in NSIP $\alpha$-SMA mRNA levels correlated with the invasion. Thus, it is reasonable to assume that the invasive capacity of myofibroblasts is connected to the amount of intracellular actin filaments and $\alpha$-SMA.

Fireman et $a l^{28}$ have studied BAL fluid samples in which the $\alpha$-actin content of alveolar fibroblasts was characterized by immunohistochemistry. Subsequently they investigated 

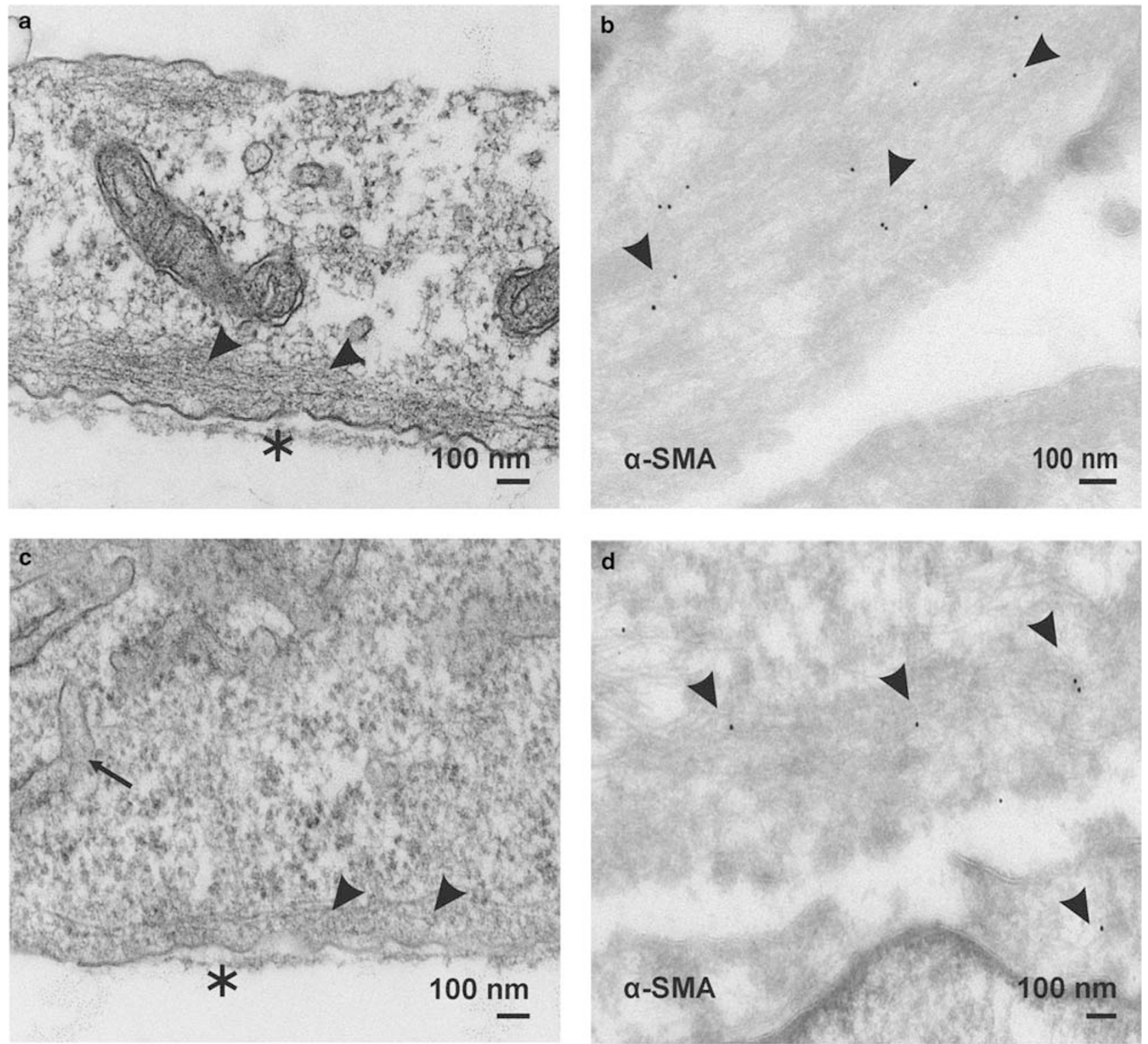

Figure 4 TEM and IEM micrographs from BAL $(\mathbf{a}, \mathbf{b})$ and lung biopsy $(\mathbf{c}, \mathbf{d})$ cultured cells of a patient with IPF exhibit similar ultrastructural features. (a) Cells cultured from BAL show features of a myofibroblast, such as intracellular actin (arrowhead) and extracellular filament bundle (asterisk) in close vicinity to the plasma membrane by TEM. (b) The $\alpha$-SMA labeling associated to intracellular filaments (arrowhead) by IEM. (c) Intracellular actin filaments (arrowhead) beneath the plasma membrane, extracellular fibronectin bundle (asterisk) and dilated rER (arrow) are revealed by TEM. (d) Labeling of $\alpha$-SMA in intracellular filaments (arrowhead) in cell cultured from lung biopsy.

the cytoskeletal proteins and the contractile properties in fibroblasts recovered from BAL fluids, in related large amounts of $150-200 \mathrm{ml}$. The study material and methods included eight IPF and seven sarcoidosis patients by ELISA, immunofluorescence and a gel contraction assay. They reported that the expression of $\alpha$-SMA was higher in IPF than in sarcoidosis. ${ }^{29}$ Moreover, they studied some cells also by EM and demonstrated that in IPF, many cells contained numerous filaments with associated dense bodies together with $\mathrm{rER}$, whereas no dense bodies were found in the cell lines from the sarcoidosis patients. ${ }^{29}$ The results of the previous studies are partly concurrent with our data. We observed the intracellular actin filaments by TEM and $\alpha$-SMA labels by IEM in several kind of ILD including IPF. Thus, ultrastructurally characteristic myofibroblasts in addition to fibroblasts were detected in sarcoidosis as well as in other types of ILD. Moreover, we were able to characterize the typical features of the myofibroblastic FNX, that is, intracellular actin filament and extracellular fibronectin in every case we studied. We confirmed our TEM studies by using IEM with the antibodies against $\alpha$-SMA and fibronectin, which are known components of the FNX, and 

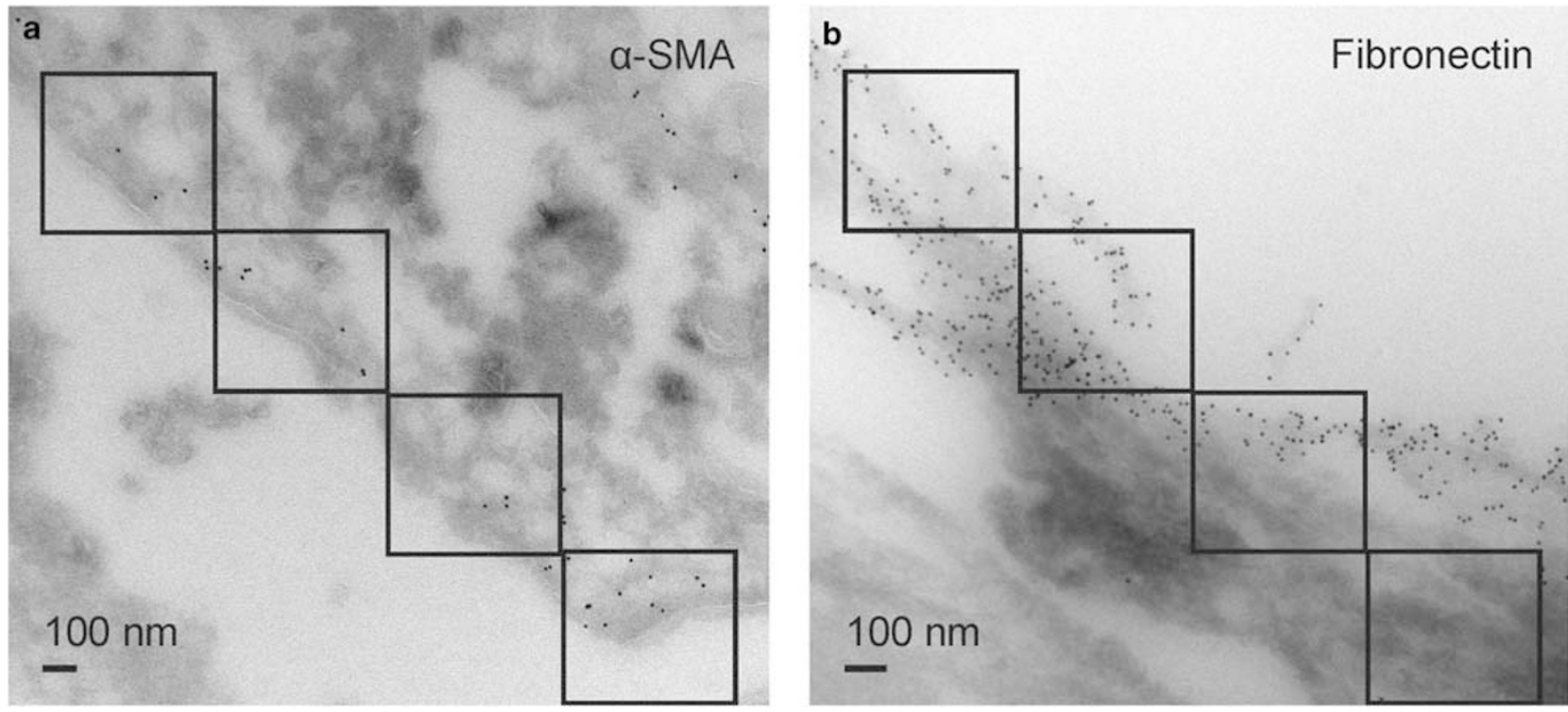

Figure 5 The quantitation of intracellular $\alpha$-SMA and extracellular fibronectin expression from BAL-derived myofibroblasts by IEM. Four rectangles (black, $0.26 \mu \mathrm{m}^{2}$ ) were systematically designated from the upper left corner to the lower right corner of the image, and gold labels were counted within each of these rectangles at a magnification of 46000 . (a) Shows a typical example of the quantitation of $\alpha$-SMA labels from a sample of an IPF patient. (b) Represents the corresponding image of the quantitation of fibronectin labels.

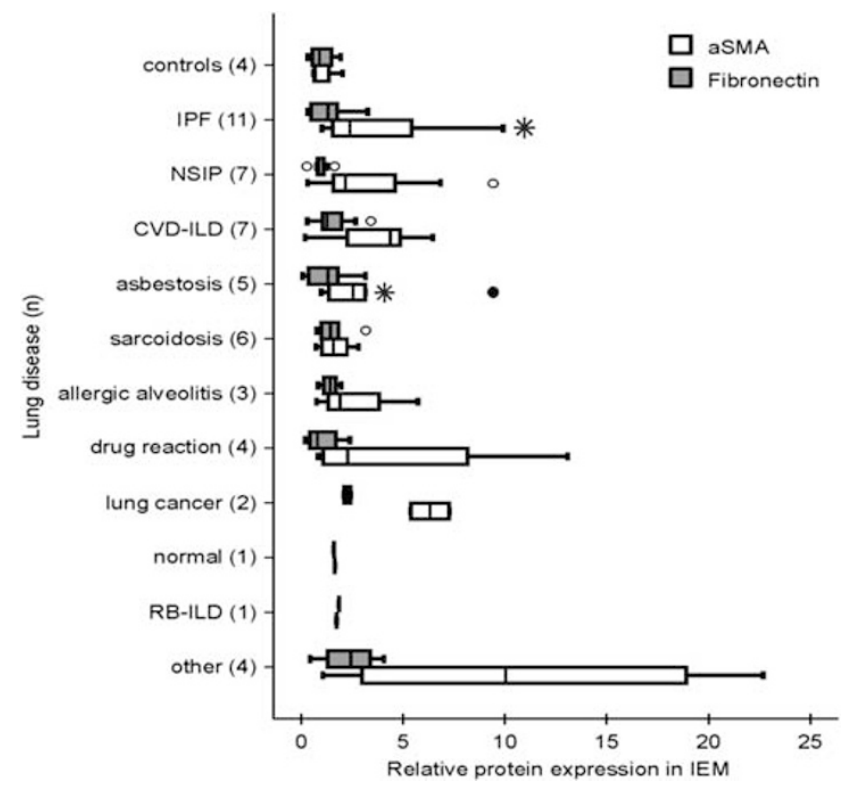

Figure 6 The quantitation of $\alpha$-SMA (white) and fibronectin (gray) protein expression in BAL-derived cells by counting gold particles from IEM sections at magnification of 46000 . The number of $\alpha$-SMA-labels is increased in cells derived from patients with IPF, CVD-ILD, asbestosis, drug reaction, lung cancer and other (asthma $(n=2)$, COPD/emphysema $(n=1)$ and vasculitis $(n=1))$. The number of fibronectin labels is increased in cells from IPF, CVDILD, asbestosis, allergic alveolitis, lung cancer and other. The numbers of $\alpha$-SMA- and fibronectin-labels have been quantified and normalized to the average number of labels in control cell lines $(n=4)$ that were cultured from lung tissue samples. The outlier (open circle) and extreme outlier (black closed circle) values are shown. When compared with control cells, IPF cells ( $P=0.019$, Mann-Whitney $U$-test) and asbestosis cells $(P=0.05$, Mann-Whitney $U$-test) expressed more $\alpha$-SMA.

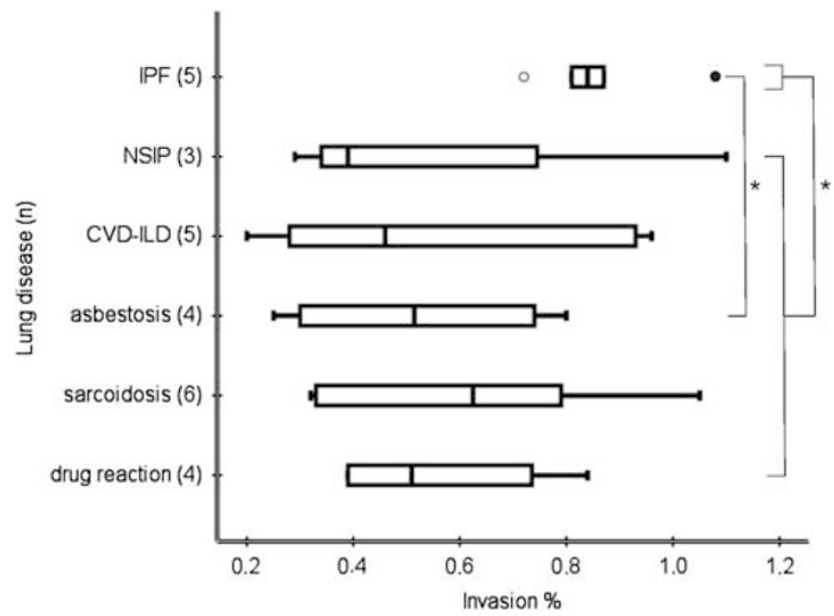

Figure 7 Cell invasion. The results are shown as percentage of invaded cells from total number of plated cells and s.d. are shown as line. Invasive capacities were evaluated by plating 50000 cells on the top of Matrigel, and the cells were allowed to invade for 2 days after which the cell amount was measured by Calcein-AM by using standard curve prepared from the same cells. Invasion was on average $0.74 \%$ (s.d. 0.41), IPF patient-derived cells display the highest invasive capacity $(0.86 \%$, s.d. 0.17$)$. In IPF, the outlier value is marked as open circle and extreme outlier value as black closed circle. ${ }^{*}$ Indicates statistical difference $<0.05$.

moreover, the levels of $\alpha$-SMA were analyzed by the quantitation of positive labels in IEM and additionally also by western blot and qRT-PCR methods.

Larsen et $a l^{30}$ studied BAL-derived fibroblasts by electron microscope and observed that the cells expressed microvilli and filopodia, and displayed intracellular and secreted 


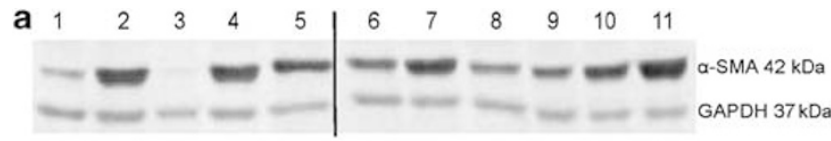

b

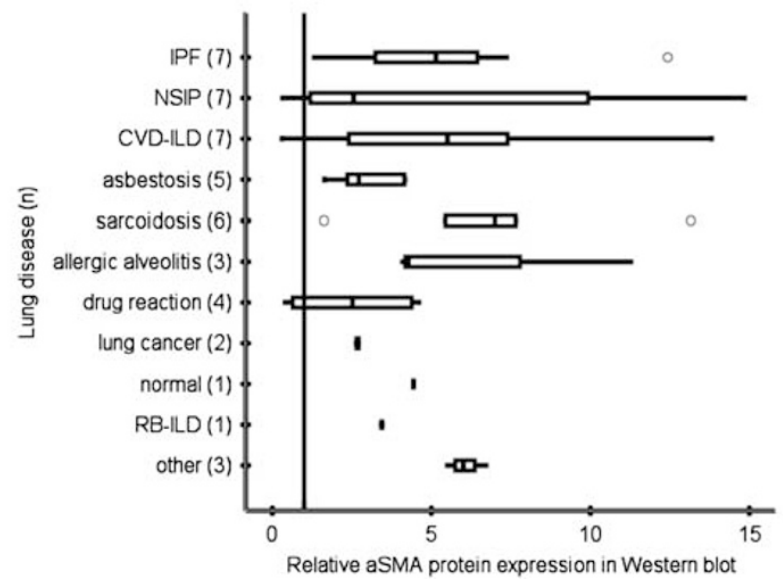

Figure 8 Western blot for $\alpha$-SMA. (a) Demonstrates the representative protein bands of $\alpha$-SMA ( $42 \mathrm{kDa}$ ) in different lung diseases. Loading control GAPDH ( $37 \mathrm{kDa}$ ) is shown. The protein bands have been grouped from two different gels. The $20 \mu \mathrm{g}$-aliquots were loaded into 12\% SDS-PAGE and run in running buffer $(25 \mathrm{mM}$ Tris, $190 \mathrm{mM}$ glycine, $0.1 \% \mathrm{SDS})$ for $1.5 \mathrm{~h}(200 \mathrm{~V}$, $100 \mathrm{~mA}$ ) and blotted in blotting buffer ( $30 \mathrm{mM}$ Tris, $0.24 \mathrm{M}$ glycine, $20 \%$ EtOH) over night $\left(40 \mathrm{~mA},+4^{\circ} \mathrm{C}\right)$. Samples are as follows: (1) control, (2) IPF, (3) NSIP, (4) CVD-ILD, (5) asbestosis, (6) sarcoidosis, (7) allergic alveolitis, (8) drug reaction, (9) lung cancer, (10) normal, (11) other (asthma $(n=2)$, vasculitis $(n=1)$ ). Molecular weight is shown in the right. (b) Shows the quantitation of $\alpha$-SMA amount. The intensities of $\alpha$-SMA were quantified and normalized to the intensity of control cells. The reference line indicates the $\alpha$-SMA protein expression of control cells. The outlier values are shown as open circles.

vesicles. In subsequent study, ${ }^{31}$ they analyzed BAL and bronchial biopsy-derived fibroblasts and observed increased migration and elevated levels of ED-A fibronectin and $\alpha$ SMA in patients with CVD-ILD and asthma. The authors noted that these observations were typical for myofibroblasts. Unlike our study, Larsen et al did not use IEM nor were these investigators able to examine the most typical ultrastructural features of myofibroblasts, such as FNX, intracellular actin, extracellular fibronectin bundles and cell junctions. In addition to native fibronectin, we have also analyzed some samples with an antibody against ED-A fibronectin, and observed that it is positive in myofibroblasts and is localized in FNX similarly to fibronectin.

We conclude that ultrastructurally typical myofibroblasts can be cultured from small volumes of diagnostic BAL fluid samples. The TEM and IEM characterization of the cells revealed several differential features in the various lung diseases. Cells cultured from the patients with ILD expressed more intracellular actin filaments by TEM than those cultured from the normal lung. Specimens from patients with fibrotic lung diseases like IPF and asbestosis expressed the highest amounts of labels of $\alpha$-SMA and fibronectin by IEM. The structure of FNXs was variable and adherens-type cell junctions were present only in part of the samples. The

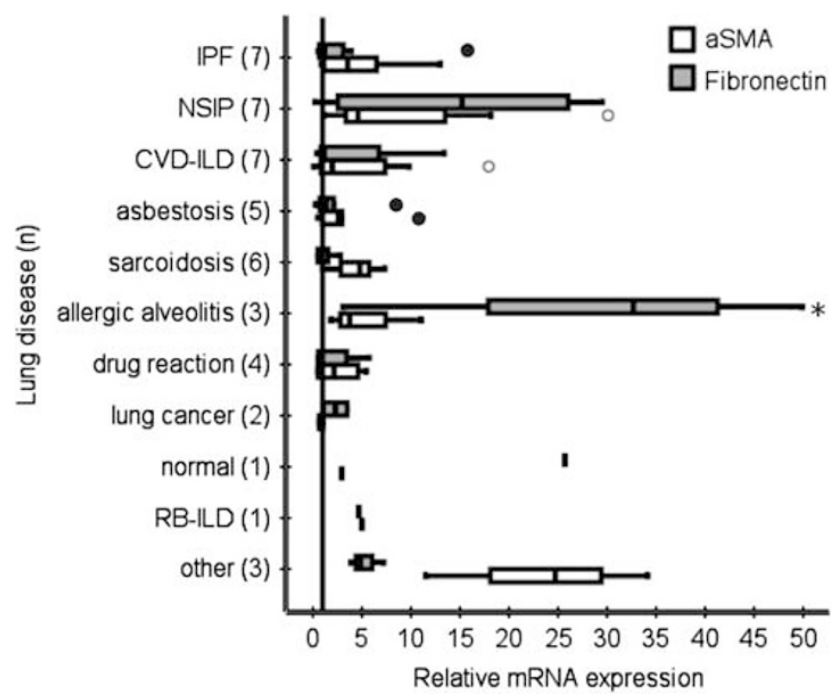

Figure 9 The quantitative RT-PCR for $\alpha$-SMA (white) and fibronectin (gray). Relative $\alpha$-SMA mRNA expression was increased in cells cultured from the patients with IPF, NSIP, CVD-ILD, sarcoidosis, allergic alveolitis and other diseases (asthma $(n=2)$ and vasculitis $(n=1))$ compared with control cells. Cells from allergic alveolitis expressed more fibronectin mRNA than IPF cells $(P=0.001$, ANOVA, Dunnett). GAPDH was used as a reference gene.

Reference line indicates the expression of $\alpha$-SMA and fibronectin mRNA in control cells. The outlier (open circle) and extreme outlier (black closed circle) values are shown.

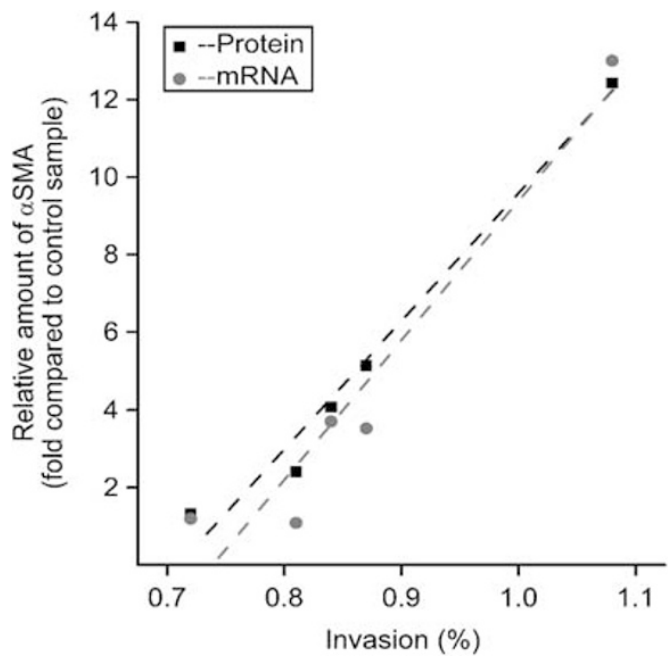

Figure 10 The invasive capacity of IPF patients $(n=5)$ correlated to the relative expression of $\alpha$-SMA of the cells derived from the IPF patients. Both $\alpha$-SMA protein (black) and $\alpha$-SMA mRNA (gray) expression show positive correlation with invasiveness $(r=0.988$ and $0.960, P=0.002$ and 0.01 , respectively).

highest invasive capacity was found in the cells derived from patients with IPF. The invasive capacity of the cells correlated with the amount of intracellular actin. Further analyses of myofibroblastic FNXs and cell junctions of various diseases may reveal more new information about ultrastructural phenomena, which could be useful in the future in the therapeutics and diagnostics of many serious lung diseases. In 
addition to biochemical and cell biological methods, the characterization of lung myofibroblasts by TEM and IEM may shed light on the pathogenesis of these different lung diseases.

Supplementary Information accompanies the paper on the Laboratory Investigation website (http://www.laboratoryinvestigation.org)

\section{ACKNOWLEDGEMENTS}

We thank Biocenter Oulu EM laboratory staff for laboratory and technical skills. The study was supported by the Academy of Finland, the Jalmari and Rauha Ahokas Foundation, the Finnish Anti-Tuberculosis Association Foundation, the Duodecim of Oulu, the Väinö and Laina Kivi Foundation, a state subsidy to the University Hospital of Oulu and the Health Care Foundation of North Finland.

\section{AUTHOR CONTRIBUTIONS}

HMK participated in cell culture experiments, collecting of study material, analyses of cell samples by electron microscopy, statistical analyses, western blot and quantitative RT-PCR experiments and manuscript preparation. STL was responsible for cell culture experiments, participated collecting of study material, western blot and quantitative RT-PCR experiments, data analysis and manuscript preparation. RTS was responsible for electron microscopic methods, analysis of electron microscopic samples, interpretation of electron microscopic results and manuscript preparation. TH participated in collecting of the study material, analysis of clinical data and manuscript preparation. ELB participated in BAL fluid samples evaluation and manuscript preparation. RB participated in statistical analyses. RK participated in the design of the study, collecting of study material, performing of bronchoscopies and BALs, analysis of electron microscopic samples, interpretation of electron microscopic results, analyses of data and manuscript preparation.

\section{DISCLOSURE/CONFLICT OF INTEREST}

The authors declare no conflict of interest.

1. Majno G, Shea SM, Leventhal M. Endothelial contraction induced by histamine-type mediators: an electron microscopic study. J Cell Biol 1969;42:647-672.

2. Majno G, Gabbiani G, Hirschel BJ, et al. Contraction of granulation tissue in vitro: similarity to smooth muscle. Science 1971;173:548-550.

3. Gabbiani G, Ryan GB, Majne G. Presence of modified fibroblasts in granulation tissue and their possible role in wound contraction. Experientia 1971;27:549-550.

4. Singer II. The fibronexus: a transmembrane association of fibronectincontaining fibers and bundles of $5 \mathrm{~nm}$ microfilaments in hamster and human fibroblasts. Cell 1979;16:675-685.

5. Singer II, Kawka DW, Kazazis DM, et al. In vivo co-distribution of fibronectin and actin fibers in granulation tissue: immunofluorescence and electron microscope studies of the fibronexus at the myofibroblast surface. J Cell Biol 1984;98:2091-2106.

6. Singer II, Kazazis DM, Kawka DW. Localization of the fibronexus at the surface of granulation tissue myofibroblasts using double-label immunogold electron microscopy on ultrathin frozen sections. Eur J Cell Biol 1985;38:94-101.

7. Desmouliere A, Chaponnier C, Gabbiani G. Tissue repair, contraction, and the myofibroblast. Wound Repair Regen 2005;13:7-12.

8. Eyden B. The myofibroblast: phenotypic characterization as a prerequisite to understanding its functions in translational medicine. J Cell Mol Med 2008;12:22-37.

9. Eyden B. The myofibroblast: an assessment of controversial issues and a definition useful in diagnosis and research. Ultrastruct Pathol 2001;25:39-50.
10. Eyden B. The fibronexus in reactive and tumoral myofibroblasts: further characterisation by electron microscopy. Histol Histopathol 2001;16:57-70.

11. Eyden B, Banerjee SS, Shenjere $P$, et al. The myofibroblast and its tumours. J Clin Pathol 2009;62:236-249.

12. Eyden BP. Brief review of the fibronexus and its significance for myofibroblastic differentiation and tumor diagnosis. Ultrastruct Pathol 1993;17:611-622.

13. Kaarteenaho-Wiik $R$, Sademies $O$, Paakko $P$, et al. Extracellular matrix proteins and myofibroblasts in granulomas of sarcoidosis, atypical mycobacteriosis, and tuberculosis of the lung. Hum Pathol 2007;38:147-153.

14. Kaarteenaho-Wiik R, Paakko $P$, Sormunen R. Ultrastructural features of lung fibroblast differentiation into myofibroblasts. Ultrastruct Pathol 2009;33:6-15.

15. Technical recommendations and guidelines for bronchoalveolar lavage (BAL). Report of the European Society of Pneumology Task Group. Eur Respir J 1989;2:561-585.

16. Silcocks PB. Measuring repeatability and validity of histological diagnosis-a brief review with some practical examples. J Clin Pathol 1983;36:1269-1275.

17. Slot JW, Geuze HJ. A new method of preparing gold probes for multiple-labeling cytochemistry. Eur J Cell Biol 1985;38:87-93.

18. Livak KJ, Schmittgen TD. Analysis of relative gene expression data using real-time quantitative PCR and the 2 (-delta delta $C(T)$ ) method. Methods 2001;25:402-408.

19. Rothman KJ. No adjustments are needed for multiple comparisons. Epidemiology 1990;1:43-46.

20. Badri L, FAU - Murray S, Murray S, et al. Mesenchymal stromal cells in bronchoalveolar lavage as predictors of bronchiolitis obliterans syndrome. Am J Respir Crit Care Med 2011;183:1062-1070.

21. Rock JR, Barkauskas CE, Cronce MJ, et al. Multiple stromal populations contribute to pulmonary fibrosis without evidence for epithelial to mesenchymal transition. Proc Natl Acad Sci USA 2011;108: E1475-E1483.

22. Hinz B, Gabbiani G. Cell-matrix and cell-cell contacts of myofibroblasts: role in connective tissue remodeling. Thromb Haemost 2003;90: 993-1002.

23. Hinz B, Pittet $P$, Smith-Clerc J, et al. Myofibroblast development is characterized by specific cell-cell adherens junctions. Mol Biol Cell 2004;15:4310-4320.

24. Gabbiani G, Chaponnier C, Huttner I. Cytoplasmic filaments and gap junctions in epithelial cells and myofibroblasts during wound healing. J Cell Biol 1978;76:561-568.

25. Follonier L, Schaub S, Meister JJ, et al. Myofibroblast communication is controlled by intercellular mechanical coupling. J Cell Sci 2008;121(Pt 20):3305-3316.

26. White ES, Thannickal VJ, Carskadon SL, et al. Integrin alpha4beta1 regulates migration across basement membranes by lung fibroblasts: a role for phosphatase and tensin homologue deleted on chromosome 10. Am J Respir Crit Care Med 2003;168:436-442.

27. Lovgren AK, Kovacs JJ, Xie $\mathrm{T}$, et al. Beta-arrestin deficiency protects against pulmonary fibrosis in mice and prevents fibroblast invasion of extracellular matrix. Sci Transl Med 2011;3:74ra23.

28. Fireman E, Kivity S, Shahar I, et al. Secretion of stem cell factor by alveolar fibroblasts in interstitial lung diseases. Immunol Lett 1999;67:229-236.

29. Fireman E, Shahar I, Shoval S, et al. Morphological and biochemical properties of alveolar fibroblasts in interstitial lung diseases. Lung 2001;179:105-117.

30. Larsen K, Tufvesson E, Malmstrom J, et al. Presence of activated mobile fibroblasts in bronchoalveolar lavage from patients with mild asthma. Am J Respir Crit Care Med 2004;170:1049-1056.

31. Larsen K, Malmstrom J, Wildt $M$, et al. Functional and phenotypical comparison of myofibroblasts derived from biopsies and bronchoalveolar lavage in mild asthma and scleroderma. Respir Res 2006;7:11. 